\title{
Implementation of Virtual Lab Media Using Problem Based Learning Models to Increase Students Learning Achievement Based STIFI and Learning Style Test
}

\author{
Freddy Tua Musa Panggabean ${ }^{1}$, Saronom Silaban ${ }^{2}$, Murniaty Simorangkir ${ }^{3}$ \\ \{freddypanggabean234@yahoo.com \} \\ Department of Chemistry, Universitas Negeri Medan, Medan 20221, Indonesia ${ }^{1,2,3}$
}

\begin{abstract}
This research aims to implement the Virtual Lab media using Problem Based Learning assisted to increasing the students' learning achievements in Cahaya Medan High School and finding out whether there are differences in student learning achievements using virtual lab media and Problem Based Learning models in terms of the STIFIn test and learning style tests This study uses a pretest-posttest group design. Data analysis techniques using One Way Anova analysis. The results showed: (1) there were differences in the increase in students' chemistry learning achievements in terms of the STIFIn test, and (2) there were differences in the increase in students' chemistry learning achievements in terms of learning style tests.
\end{abstract}

Keywords: Virtual Lab Media, Problem Based Learning Models. STIFIn, Learning Style, Learning Achievement.

\section{Introduction}

Education is a conscious effort that is done so that students can achieve certain goals to reach maturity (Utami et al. 2016). Education is not only the process of transferring knowledge possessed by the teacher to students but also developes a good personality to students in terms of knowledge, attitudes and skills (Ratna \& Sani, 2017). In fact, during the learning process, students are less actively involved, tend to just accept the subject presented and result in less optimal achievement (Fauzan et al. 2017).

One effort to overcome these problems is apply the Problem Based Learning. Problem Based Learning provides opportunities for students to be responsible for their own learning (Ulger, 2018). In the Problem Based Learning, the role of the teacher is to present a variety of authentic problems so that it is clear and requires the activeness of students to be able to solve the problem (Wulandari \& Surjono, 2013).

In the learning process not only pay attention to the external factors of students, known as the learning model, but also pay attention to the internal factors of the student, namely the personality type (Utami et al. 2016). The STIFIn concept can describe a person as a whole as well as his social relationships, even if only with the information of the brain hemisphere and the dominant brain layer (Poniman, 2016). In the STIFIn concept, there are 5 brain hemispheres in humans where there is only one dominant (Hiday, 2017). In STIFIn, the learning patterns of each machine-intelligence are modeled as follows: Sensing (S), Thinking (T), Intuiting (I), Feeling (F) and Instinct (In) (Rafianti \& Pujiastutti, 2017). 
In addition to the use of learning models, other efforts that can be done to overcome the problems of student learning achievements are the use of learning media, one of them is virtual lab media. Virtual chemlab is a virtual software that can be used for laboratory simulations on chemical subject that allows the educators to make their own laboratory simulations (Naipospos, 2016). Sari et al. (2014), reported that Learning by using Virtual lab media provides improvement of learning achievements. The research was conducted by Panggabean et al. (2017) state that, the learning achievements of students who were taught with virtual lab media were higher than those of students who were taught with real lab media. Linked with Hikmah's research, et al. (2017) the influence of the application of virtual simulations in improving students' conceptual understanding.

This study aims to determine differences in the improvement of student learning achievements using virtual lab media with Problem Based Learning Model terms of STIFIn tests (Sensing, Thinking, Intuiting, Feeling and Instinct), and learning style tests (Visual, Auditory and Kinesthetic).

\section{Material And Methods}

\subsection{Time and Place Allocation}

Research was conducted at the Medan Cahaya High School which is located at Hayam Wuruk street No. 11 Medan. The time of the research was carried out in the odd semester academic years of 2018/2019.

\subsection{Research Procedure}

The research was carried out in several stages as follows: 1) giving pretest, STIFIn test, and learning style before treatment; 2) implementation of virtual lab media using by Problem Based Learning Model with the STIFIn method; 3) giving posttest after treatment.

The research method used was experimental research with pretest-posttest group design (Silitonga, 2014). The sample of this study was 30 students. Data collection methods are carried out by learning test results, STIFIn tests, learning style tests and personality tests.

\subsection{Data Analysis}

Data analysis techniques to be used includes: 1) tabulation of research results data; 2) determination of normalized gain; 3) data normality test using the approach KolmogorovSmirnov; 4) data homogenity test using approach Levene's Test; and 5) hypothesis testing using the Analysis of One Ways Anova variance (Silitonga, 2014).

\section{$3 \quad$ Result And Discussion}

\subsection{Description of Student Learning Achievements}

Before being given treatment, students are given a pretest, a STIFIn test, and a learning style test. Furthermore, students were given treatment using virtual lab media with Problem Based 
Learning models. At the end of the meeting students are given again a post-test to find out student learning achievements. Increased student learning achievements are calculated by normalized gain techniques.

Table 1. Increasing of Learning Achievements Based on STIFIn test

\begin{tabular}{clrrr}
\hline \multicolumn{1}{c}{ STIFIn } & \multicolumn{1}{c}{ Statistic } & Pretest & Posttest & \multicolumn{1}{c}{ Gain } \\
\hline \multirow{5}{*}{ Sensing } & N & 6 & 6 & 6 \\
& Mean & 17.50 & 33.67 & 0.71 \\
& Std. Deviation & 3.017 & 0.816 & 0.034 \\
\multirow{5}{*}{ Thinking } & N & 6 & 6 & 6 \\
& Std. Deviation & 17.50 & 35.83 & 0.81 \\
& & 1.225 & 1.169 & 0.055 \\
Intuiting & Mean & 6 & 6 & 6 \\
& Std. Deviation & 16.83 & 37.17 & 0.88 \\
& & 2.401 & 1.169 & 0.048 \\
Feeling & N & 6 & 6 & 6 \\
& Mean & 17.17 & 34.67 & 0.77 \\
& Std. Deviation & 1.329 & 1.033 & 0.038 \\
& N & 6 & 6 & 6 \\
& Mean & 17.33 & 31.67 & 0.63 \\
& Std. Deviation & 0.816 & 1.211 & 0.063 \\
\hline \multirow{5}{*}{ Instinct } & & & &
\end{tabular}

Students with the Sensing type from the pretest results obtained an average score of 17.50 and an average post-test score of 33.67 and an average increase in learning Achievements (gain score) of 0.71 (high). Students with Thinking-type got an average pretest score of 17.50 and an average posttest score of 35.83 with an average gain score of 0.81 (high). Students with Intuiting type got an average pretest score of 16.83 and an average posttest got score of 37.17 with an average gain score of 0.88 (high). Students with the type of Feeling got an average pretest score of 17.17 and an average posttest score of 34.67 with an average gain score of 0.77 (high). Students with Instinct type got an average pretest score of 17.33 and an average posttest score of 31.67 with an average gain score of 0.63 (moderate). 
Table 2. Increasing of Learning Achievements Based on Learning Style Test

\begin{tabular}{llrrr}
\hline Learning Style & \multicolumn{1}{c}{ Statistic } & \multicolumn{1}{c}{ Pretest } & Posttest & \multicolumn{1}{c}{ Gain } \\
& N & 10 & 10 & 10 \\
\multirow{3}{*}{ Visual } & Mean & $17: 50$ & 32.70 & 0.67 \\
& Std. Deviation & 2,273 & 1,567 & 0.069 \\
\hline \multirow{4}{*}{ Auditory } & N & 10 & 10 & 10 \\
& Mean & 17.30 & 34.60 & 0.76 \\
& Std. Deviation & 1,252 & 1,578 & 0.066 \\
\hline \multirow{3}{*}{ Kinesthetic } & N & 10 & 10 & 10 \\
& Mean & 17.00 & 36.50 & 0.85 \\
& Std. Deviation & 1,944 & 1,434 & 0.065 \\
\hline
\end{tabular}

Data on increasing of students learning achievements based on learning style test are seen in table 2.

Students with visual learning styles from the pretest results got an average score of 17.50 and an average posttest score of 32.70 and an average increase in learning achievements (gain score) of 0.67 (medium). Students with auditory learning styles got an average pretest score of 17.30 and an average posttest score of 34.60 with an average gain score of 0.76 (high). Students with kinesthetic learning styles got an average pretest score of 17.00 and an average posttest score of 36.50 with an average gain score of 0.85 (high).

\subsection{Hypothesis Testing}

Hypothesis testing is done to analyze differences in the improvement of student learning achievements (gain scores) using virtual lab media with Problem Based Learning model terms of STIFIn tests, and learning style tests. Hypothesis testing was carried out using variance One Way Analysis technique.

\subsubsection{Hypothesis Test Based on the STIFIn Test}

Differences in the increase in student learning achievements based on the STIFIn test were analyzed by One Way ANOVA as in table 3 .

Table 3. Hypothesis Test Results Based on the STIFIn Test

\begin{tabular}{lrrrrr}
\multicolumn{6}{c}{ ANOVA } \\
& $\begin{array}{l}\text { Sum of } \\
\text { Squares }\end{array}$ & Df & $\begin{array}{c}\text { Mean } \\
\text { Square }\end{array}$ & F & Sig. \\
\hline $\begin{array}{l}\text { Between } \\
\text { Groups }\end{array}$ & .210 & 4 & .052 & 22.203 & .000 \\
$\begin{array}{l}\text { Within } \\
\text { Groups }\end{array}$ & .059 & 25 & .002 & & \\
Total & .269 & 29 & & & \\
\hline
\end{tabular}

The results of the analysis on Table 3, obtained the Fcount of 22,203 with the sig. value. 0.000 $<0.05$, so it can be concluded that there are differences in the increase in student learning 
achievements (gain scores) using virtual lab media with the Problem Based Learning models terms of the STIFIn test.

To find out which group gives a better influence (based on the STIFIn test), then do the Tukey test. Tukey test results are presented in table 4

Table 4. Tukey Test Results Based on the STIFIn Test

\begin{tabular}{lccccc}
\hline & \multicolumn{5}{c}{ Sig. } \\
\cline { 2 - 6 } & $\begin{array}{c}\text { Sensi } \\
\text { ng }\end{array}$ & $\begin{array}{c}\text { Thinki } \\
\text { ng }\end{array}$ & $\begin{array}{c}\text { Intuitin } \\
\mathrm{g}\end{array}$ & $\begin{array}{c}\text { Feelin } \\
\mathrm{g}\end{array}$ & $\begin{array}{c}\text { Insti } \\
\text { nct }\end{array}$ \\
\hline Sensing & - & .014 & .000 & .373 & .05 \\
& & & & & 3 \\
Thinking & .01 & - & .473 & & .17 \\
& & & .000 & & 3 \\
Intuiting & .17 & .000 &.- & .004 & .00 \\
& & & & & 0 \\
Feeling & .37 & .473 & .004 & - & .00 \\
& & & & & 1 \\
Instinct. & .05 & 000 & .000 & .001 & - \\
\hline
\end{tabular}

The results of further tests (Tukey's test) show that there is a difference in the increase in learning achievements (gain scores) between students who have the type of Sensing with Thinking $(\mathrm{p}=0.014)$, between Sensing and Intuiting $(\mathrm{p}=0.000)$, between Thinking with Instinct $(p=0.000)$, between Intuiting with Feeling $(p=0.004)$, between Intuiting and Instinct $(\mathrm{p}=0,000)$, and between Feeling and Instinct $(\mathrm{p}=0.001)$. Tukey's test results also showed no difference in the increase in learning achievements (gain scores) between students who had the type of Sensing with Feeling $(p=0.373)$, between Sensing with Instinct $(p=0.053)$, between Thinking with Intuiting $(\mathrm{p}=0.173)$ and between Thinking with Feeling $(\mathrm{p}=0.473)$.

The results of study show that students with the Intuiting type got an average increase in learning of achievements (0.88) higher than students with the type of Feeling (0.77), Sensing (0.71) and Instinct type (0.63). Students with the Thinking type got an average increase in learning of achievements (0.81) higher than students with the Sensing type (0.71) and Instinct type (0.63). Students with the type of Feeling got an average increase in learning of achievements (0.77) higher than students with Instint type (0.63).

\subsubsection{Hypothesis Test Based on Learning Style Test}

Differences in the increase in student learning achievements based on the learning style test were analyzed by One Way ANOVA as in table 5. 
Table 5. Hypothesis Test Results Based on Learning Style Test.

\begin{tabular}{lrrrrr}
\multicolumn{5}{c}{ ANOVA } \\
\hline & $\begin{array}{c}\text { Sum of } \\
\text { Squares }\end{array}$ & Df & $\begin{array}{c}\text { Mean } \\
\text { Square }\end{array}$ & F & Sig. \\
\hline Between Groups & .148 & 2 & .074 & 16554 & .000 \\
Within Groups & .121 & 27 & .004 & & \\
Total & .269 & 29 & & & \\
\hline
\end{tabular}

Analysis results in Table 6, the value of Fcount of 18554 with sig. $0.000<0.05$, so it can be concluded that there are differences in the increase in student learning achievements (gain scores) using virtual lab media with Problem Based Learning models terms of the Learning Style test.

To find out which group gives a better influence (based on the learning style test), then do the Tukey test. Tukey test results are presented in table 6 .

Table 6. Tukey Test Results Based on Learning Style Test

\begin{tabular}{lrrr}
\hline & \multicolumn{3}{c}{ Sig. } \\
\cline { 2 - 4 } & Visual & Auditory & Kinesthetic \\
\hline Visual & - & .015 & .000 \\
Auditor & .015 & - & .028 \\
$\begin{array}{l}\text { Kinesth } \\
\text { etic }\end{array}$ & .000 & .028 & - \\
\hline
\end{tabular}

The results of Tukey test show that there is a difference in the increase in learning achievements (gain scores) between students who have Visual learning styles with Auditory learning styles $(p=0.015)$, between Visual learning styles and Kinesthetic $(p=0.000)$ and between Auditory learning styles and Kinesthetic learning styles $(\mathrm{p}=0.028)$.

The results of study show that students with kinesthetic learning styles got an average increase in learning of achievements (0.85) higher than students with auditory (0.76) and visual learning styles (0.67). Students with auditory learning styles got an average increase in learning of achievements (0.76) higher than students with visual learning styles (0.67).

\section{Conclusion}

The result of this study contained differences in the increase in students' chemistry learning achievements in terms of the STIFIn test $(\mathrm{p}=0.000)$. Students with the Intuiting type got an average increase in learning achievements (0.88) higher than students with the type of Feeling (0.77), Sensing (0.71) and Instinct type (0.63). Students with the Thinking type got an average increase in learning o achievements $(0.81)$ higher than students with the Sensing type (0.71) and Instinct type (0.63). Students with the type of Feeling got an average increase in 
learning achievements (0.77) higher than students with Instint type (0.63). The difference in the increase in students' chemistry learning achievements in terms of learning style tests $(\mathrm{p}=$ 0.000). Students with Kinesthetic learning styles got higher learning achievements (0.85) higher than students with Auditory learning styles (0.76) and Visual (0.67). Students with auditory learning styles got higher learning achievements (0.76) higher than students with Visual learning styles (0.67). While the difference in the increase in students' chemistry learning achievements in terms of personality tests $(p=0.000)$. Students with Melancholy personality gain an average increase in learning achievements (0.84) higher than students with Plegmatic personality (0.70).

Acknowledgments. The authors would like to thank the Medan State University Research Institute for funding this research in accordance with contract No. 282 / UN33.8 / PL / 2018.

\section{References}

[1] Fauzan, M., Gani, A., Syukri, M.: Penerapan Model Problem Based Learning Pada Pembelajaran Materi Sistem Tata Surya Untuk Meningkatkan Hasil Belajar Siswa, Jurnal Pendidikan Sains Indonesia, vol. 5, no. 1, pp.27-35.(2017)

[2] Hiday.: I Know You. Kenali Bahasa Cinta Orang Tercinta, Raih Keluarga Sukses-Mulia, Jakarta: STIFin Institute.(2017)

[3] Hikmah, N., Saridewi, N., Agung, S.: Penerapan Laboratorium Virtual Untuk Meningkatkan Pemahaman Konsep Siswa, Jurnal Kimia dan Pendidikan, vol. 2, no. 2, pp.184-195(2017)

[4] Naipospos, F.: Perbedaan Hasil Belajar Dan Aktivitas Siswa Yang Diajarkan Dengan Problem Based Learning (PBL) Menggunakan Real Lab dan Virtual Chemlab Pada Materi Titrasi Asam dan Basa, Thesis, Medan: Pendidikan Kimia, Universitas Negeri Medan (2016)

[5] Panggabean, F.T.M., Silaban, R., Hutabarat, W.: Application of Discovery Learning Models Using Virtual Lab, Real Lab and Computer Animations to Increase Student Learning Result Reviewed by The Ability of Critical Thing Students , Proceedings of the 2nd Annual International Seminar on Transformative Education and Educational Leadership (The 2ndAISTEEL).(2017)

[6] Poniman, F.: 9 Personaliti Genetik, Bekasi: Yayasan STIFIn (2016)

[7] Rafianti, I., Pujiastutti, H.: Analysis of Students Mathematical Power in Terms of Stifin Test, Journal of Mathematics Education, vol. 6, no. 1, pp.29-36 (2017)

[8] Ratna, D.S., Sani, R.A.: Peran Guru Fisika Dalam Penguatan Pendidikan Karakter Siswa SMA, Jurnal Pendidikan Fisika (2017)

[9] Sari, D.K., Mulyani, B., Mulyani, S.: Studi Komparasi Metode Pembelajaran Kooperatif Team Assisted Individualization (TAI) Dan Cooperative Problem Solving (CPS) Terhadap Prestasi Belajar Ditinjau Dari Kemampuan Matematik Siswa Pada Materi Kelarutan dan Hasil Kali Kelarutan Kelas XI IPA SMA Negeri 1 Banyudono Tahun Pelajaran 2012/2013, Jurnal Pendidikan Kimia (JPK), vol. 3, no. 1, pp.51-57.(2014)

[10] Silitonga, P.M.: Statistik, Medan: FMIPA UNIMED, (2014)

[11] Ulger, K.: The Effect $f$ Problem Based Learning on the Creative Thingking and Critical Thingking Disposition of Sutdent in Visual Art Education, Interdisciplinary Journal of Problem Based Learning, vol. 12, no. 1.(2018)

[12] Utami, L., Budiyono., Riyadi.: Eksperimentasi Model Pembelajaran TTW dan NHT Pada Materi Relasi dan Fungsi Ditinjau dari Tipe Kepribadian Siswa SMP Se-Surakarta, Prosiding Seminar Matematika dan Pendidikan Matematika, pp.195-204 (2016)

[13] Wulandari, B., Surjono, H.D.: Pengaruh problem Based Learning Terhadap Hasil Belajar Ditinjau dari Motivasi Belajar PLC di SMK, Jurnal Pendidikan Vokasi, vol. 3, no. 2, pp.178-191 (2013) 
